\title{
Report about the Success of Indian Welders at "IIW - CWS - ARC CUP - 2017 (International Welding Competition), held at SHANGHAI - CHINA, between 25th to 30th June, 2017"
}

We take great pleasure in conveying to you, the "Grand Success" of Indian Welder Competitors at recently held "IIW - CWS - ARC CUP - 2017" (International Welding Competition), at Shanghai - China, between 25th to 30th June, 2017. This was only the second time that Indian Welders participated in this competition. These three welders were winners of the National Competition held at Kolkata in December, 2016. IIW holds this National competition every year. Following is the final ranking of the three Indian Welders, who participated in this International competition, as officially conveyed to us by the Organising Committee

1. Mr. Ramesh Gawande : 2nd place of 1st grade prize of Adult Group in 111/SMAW Process

2. Mr. Durga Bhunja : 3rd place of 1st grade prize of Youth Group in 135/GMAW Process

3. Mr. Durga Bhunja : 3rd grade prize of Youth Group in Finished-product Welding

4. Mr. Pratik Kasare won Excellent Prize

5. India Team was awarded a Bronze Cup.

In this ARC CUP, 16 countries participated and the number of competitors was 154 . This competition has been held so far by Chinese Welding Society (CWS) with a large sponsorship by Chinese companies. From this year, the International Welding Institute (IIW) has also promoted and supported this competition. Thus the competition is called "IIW - CWS - ARC CUP - 2017 (International Welding Competition)".

Mr. Ramesh Gawande works with and was sponsored by "Nirmal Industrial Controls Limited, Asangaon", Maharashtra.

Mr. Durga Bhunja works with and was sponsored by "KEMPII India Pvt. Limited, Chennai".

Mr. Pratik Kasare works with and was sponsored by "Mahindra \& Mahindra, Kandivli, Mumbai".

Mr. Satish Kolekar (Engr.) of Mahindra \& Mahindra, was the Team Leader and Mr. Sujay Shelar (Engr.) of Nirmal Ind. Contr. had also accompanied the team as support for Shri Ramesh Gawande. The travel and training expenses of the India Team members were borne by their respective companies. The lodging and Boarding of the India team, was borne by the Oragnising Committee of the ARC CUP.
The Indian Team landed on 22nd June and could practice / get acclimatized a bit on 23rd June in the competition arena. The competitions were inaugurated on 24th June and Indian Competitors took part in their chosen skills on $26,27 \& 28$ th June. The results were declared with a closing ceremony on 30th June, 2017. Nobody from IIW could accompany the India Team this year, specifically for this competition. Mr. R. Srinivasan, the President of IIW \& Mr. Parimal Biswas - HSG of IIW were in Shanghai for the "IIW Assembly" and met the team members at their hotel on 27 th June. They also attended the closing ceremony on 30th June, 2017.

Mr. G. A. Soman, Chairman, IIW - National Skills Competitions - Best Welder, had been to this competition last year (at Beijing) and had learnt about the format and actual modalities of the competition in great detail. This year Mr. Soman managed to support the team continuously through e-mails and whatsapp. All the three Welders were trained at "DON BOSCO MARITIME ACADEMY" (DBMA), Mumbai. This academy is an Industrial Corporate Member (ICM) of Indian Institute of Welding for about 10 years. Mr. G. A. Soman is also the principal of this academy.

Noteworthy Happenings about this competition

1. In this years' competition, a great help was extended by another ICM of IIW namely - ADOR Limited. The M.D. Shri S. M. Bhat of ADOR Welding, got E 7015 electrodes specially made for the team to practice in India at DBMA. Else E-7015 are not popular electrodes and are also not available in India.

2. The IIW - Mumbai branch sponsored a part of the training of Mr. Ramesh Gawande

3. During the competition, the Russian and Kazakhistan welders were being given a second chance. We strongly objected about it to the Organising Committee. And taking cognizance of our complaint, their jobs of second attempt were not considered. In this particular skill (111/SMAW) our Ramesh Gawande came second!

The Grand Success of the Indian Welder team was lauded by many of the IIW members. The Indian Welder has firmly put his footprint in the International Competitions too!

G. A. Soman, Chairman, National Skills Competition - Best Welder, Indian Institute of Welding 